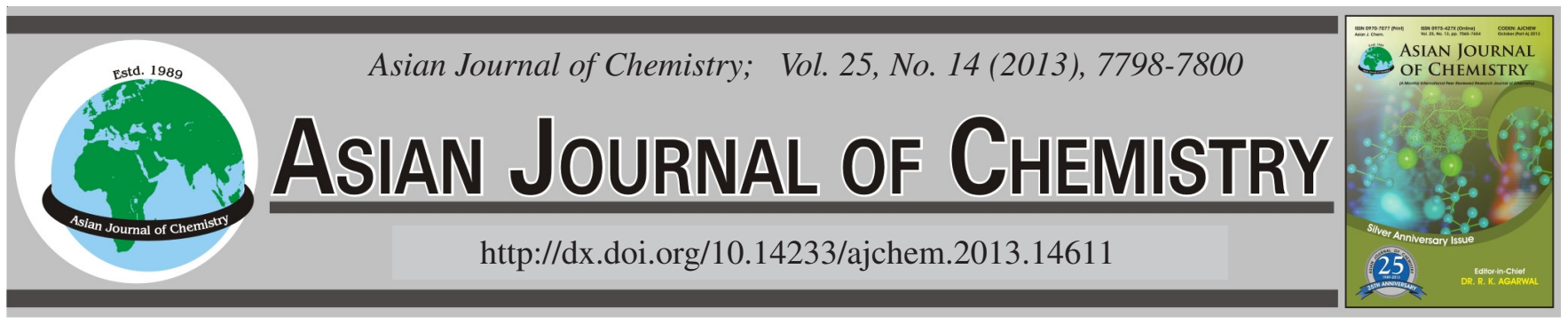

\title{
Anaerobic Baffled Reactor with Unequal Length Chambers Treating Domestic Sewage
}

\author{
TIE-Hong Song ${ }^{1}$ and YAn-JiAO GAO ${ }^{2, *}$
}

${ }^{1}$ Key Laboratory of Songliao Aquatic Environment, Ministry of Education, Jilin Architectural and Civil Engineering Institute, Changchun 130118, P.R. China

${ }^{2}$ College of Civil Engineering and Architecture, Liaoning University of Technology, Jinzhou 121001, P.R. China

*Corresponding author: Fax: +86 416 4198022; Tel: +86 416 4198727; E-mail: yanjiaogao@ 163.com

\section{INTRODUCTION}

The anaerobic baffled reactor (ABR) is one type of highrate reactor developed by McCarty and co-workers at Stanford University $^{1}$. The anaerobic baffled reactor was described as a series of upflow anaerobic sludge blanket reactors because it is divided into several chambers ${ }^{2}$. A typical anaerobic baffled reactor consists of a series of vertical baffles that direct the waste water under and over the baffles as it passes from the inlet to the outlet. The over and underflow of the liquid reduces bacteria washout, which enable the anaerobic baffled reactor to retain active biological mass without the use of any fixed media $^{3}$. The bacteria within the reactor tend to rise and settle with gas production in each chamber, but they move down the reactor horizontally at a relatively slow rate, giving rise to a sluge retention time of 100 days at a hydraulic retention time of $20 \mathrm{~h}$. The slow horizontal movement allows wastewater to come into intimate contact with the active biomass as it passes through the anaerobic baffled reactor with short hydraulic retention times $(6-20 \mathrm{~h})^{4}$.

Now anaerobic baffled reactor technology has been used in the treatment of a variety of wastewater types and the hydraulic design ensures good solids retention and good contact between biomass and organic substrate in the wastewater and therefore good organic removal rates ${ }^{5}$. The research had found the anaerobic baffled reactor technology provides good treatment rates and higher tolerance of hydraulic and organic shock loads than unbaffled anaerobic reactors for high strength applications ${ }^{6}$. Domestic sewage is regarded as low strength (relative to other anaerobic applications) and contains biodegradable material that may be particulate, colloidal or soluble. Previous research work on anaerobic baffled reactor had been undertaken on high strength wastewaters with soluble biodegradable material ${ }^{7}$. Research on domestic sewage has been limited with most work.

In this research anaerobic baffled reactor was designed as unequal length chambers with opposite folded plate form, instead of traditional equal length chambers. In addition, at top of each chamber the elastic stereo packing was positioned to prevent washout of solids. The aims of this research were: To investigate the operation temperature, The optimum hydraulic retention time and the relations of organic load and elimination rate of $\mathrm{COD}$, the relation between $\mathrm{pH}$ and COD removal,the relation between $\mathrm{pH}$ and volatile fatty acid, the effulent alkalinity variated law of different hydraulic retention time.

\section{EXPERIMENTAL}

The anaerobic baffled reactor with unequal length compartments is depicted in Fig. 1. The anaerobic baffled reactor is made of organic glass. The total length of reactor is $74 \mathrm{~cm}$, the width is $10 \mathrm{~cm}$ and the volume is $52.6 \mathrm{~L}$ the vertical flow type folding is used in reactor with folding angle $120^{\circ}$ and wave height $2 \mathrm{~cm}$. The reactor is divided into 4 chambers, Each chamber length is $15,5,25$ and $25 \mathrm{~cm}$, respectively. The electric heating wire is winded on the reactor to heat the waste water, 


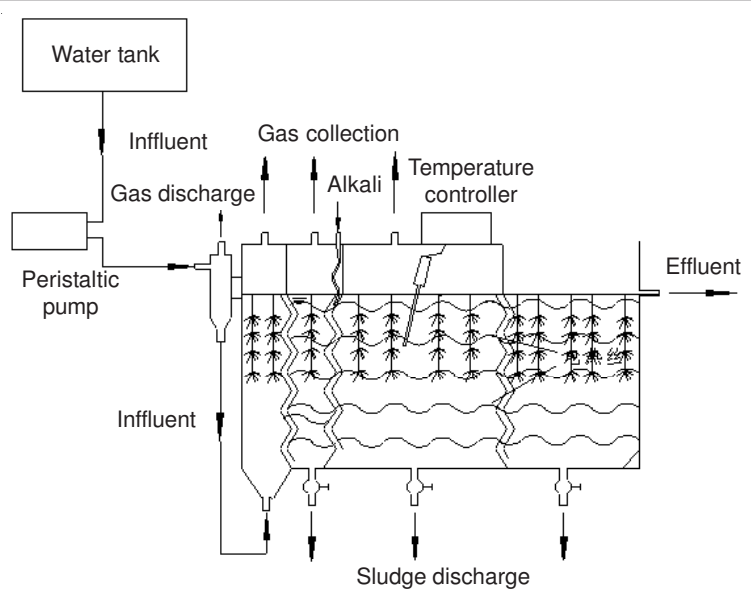

Fig. 1. Testing facility

temperature controller is used to control temperature and constant flow pump is used to control waster water flow.

Early test focuses on the efficiency of reactor and the removal rate of dissolved organic matter. In order to guarantee the water dissolved state, artificial starch dilution is used as test raw water. The high level tank is used to supply test water and flow meter is used to control water flow. Inoculated sludge is derived from the UASB pool of corn processing wastewater treatment plant. In the starting period, the concentration of the influent COD was $1000 \mathrm{mg} / \mathrm{L}$, reactor temperature is controlled in $28-32{ }^{\circ} \mathrm{C}$, the hydraulic load is increased from 2.26-5.30 $\mathrm{m}^{3} /\left(\mathrm{m}^{2} \mathrm{~d}\right)$, accordingly, hydraulic retention time is decreased from 24 to $12 \mathrm{~h}$. After 1 week, elastic stereo filler is covered milky white anaerobic filamentous bacteria, After 60 days, reactor COD removal rate was close to $80 \%$ and reach a stable state.

The data sheet of experimental examination method was in Table-1.

TABLE-1

DATA SHEET OF EXPERIMENTAL EXAMINATION METHOD

\begin{tabular}{ccc}
\hline Testing item & Analysis method & Testing frequency \\
\hline COD & $\begin{array}{c}\text { High pressure steam } \\
\text { method }\end{array}$ & 1 time 2 day \\
Volatile fatty acid & Acid base titration & 1 time 2 day \\
pH & pH 3-29Aacidity meter & 1 time a day \\
INT-dehydrogenase & LD-2Acentrifuge, & 1 time 2 day \\
activity & 721spectrophotometer \\
Microorganism & $\begin{array}{c}\text { Microscope, biochemical } \\
\text { incubator }\end{array}$ & 1 time a week \\
\hline
\end{tabular}

\section{RESULTS AND DISCUSSION}

Any kind of microorganisms has a certain temperature range and anaerobic bacteria are not exception. A test was designed to determine the optimal operation temperature of anaerobic bacteria in this system. Anaerobic bacteria taken from No. 4 chamber were cultured at the temperatures 20$40{ }^{\circ} \mathrm{C}$ for $0.5 \mathrm{~h}$ and INT-dehydrogenase activity was investigated. The relations between INT-dehydrogenase activity and temperature is shown in Fig. 2. In Fig. 2, when temperatrue increase from 20 to $39^{\circ} \mathrm{C}$, INT-dehydrogenase activity increase from $0.187-0.5$, when continue to increase the temperature, INT- dehydrogenase activity decrease. Therefore, the optimal

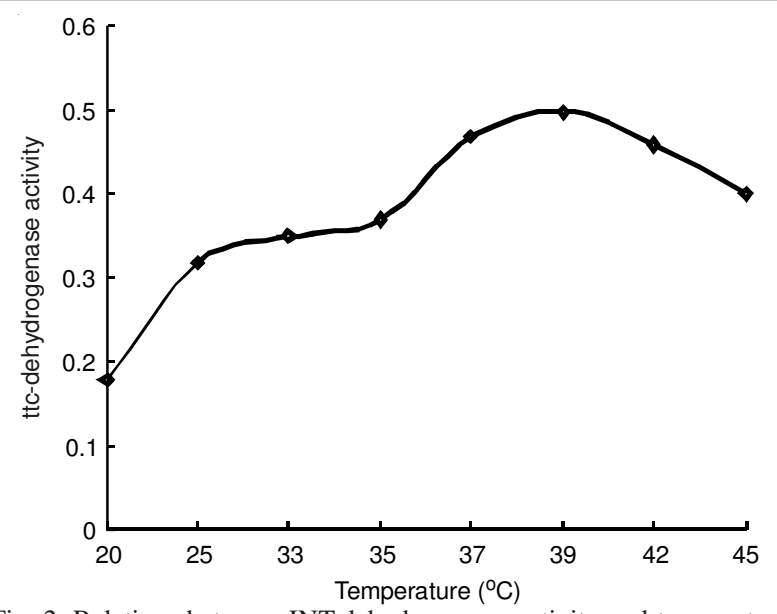

Fig. 2. Relations between INT-dehydrogenase activity and temperature

operation temperature of anaerobic bacteria in this system is $39^{\circ} \mathrm{C}$. But if the system is operated at $39^{\circ} \mathrm{C}$, it will cause large energy consumption. The ideal temperature is controled at $(30$ $\pm 1)^{\circ} \mathrm{C}$ in our test and the activity is up to 0.35 .

After the start-up test completion, influent COD is controlled about $1000 \mathrm{mg} / \mathrm{L}$, hydraulic retention time is decreased gradually, namely 12-10-8-6-4 way. At each hydraulic retention time, anaerobic baffled reactor runs $7 \mathrm{~d}$, totally running 2 months. Fig. 3 is the COD removal under different hydraulic retention time. Fig. 3 shows, hydraulic retention time is more long, the removal rate of COD is higher. When hydraulic retention time is greater than $6 \mathrm{~h}$, effluent COD is less than $100 \mathrm{mg} / \mathrm{L}$. If we reduce the hydraulic retention time, COD removal rate is smaller. Although the COD removal rate increases with hydraulic retention time increasing, when hydraulic retention time is beyond $10 \mathrm{~h}, \mathrm{COD}$ removal rate decreased. Therefore, infinite extenting hydraulic retention time can not improve the removal rate of COD, instead, the entire system volume will increase, is not economic. The optimum hydraulic retention time is $6 \mathrm{~h}$, because for low concentration wastewater, reaction will mostly be completed in a short period of time and the COD removal rate is beyond $90 \%$.

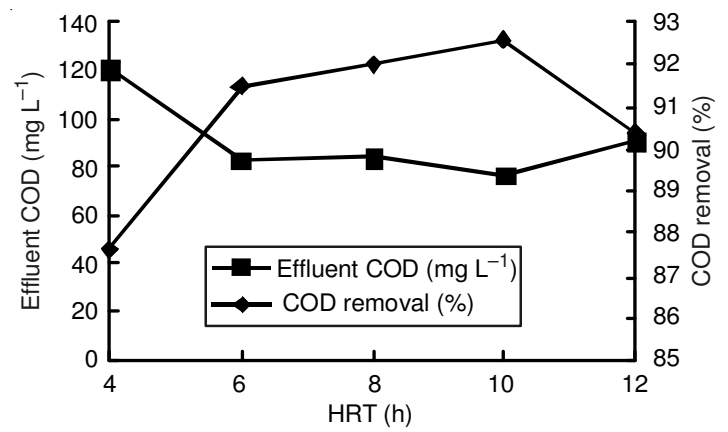

Fig. 3. Relationship betweem hydraulic retention time and removal rate of COD

Under the condition of $30^{\circ} \mathrm{C}$, hydraulic retention time 6 $\mathrm{h}$, inffulent COD concentration decreased gradually, namely 1000-900-800-700-600-500 mg/L and at each COD concentration anaerobic baffled reactor is operated $7 \mathrm{~d}$, totally running 2 months. Fig. 4 is the relationship between organic loading rate and removal rate of COD. From Fig. 4, the hydraulic 
retention time is controlled at $6 \mathrm{~h}$, inffulent COD concentration is $1000-500 \mathrm{mg} / \mathrm{L}$, the effluent COD can reach $50-100 \mathrm{mg} / \mathrm{L}$ and the removal rate of COD is in 85-95\%. Anaerobic baffled reactor for low concentration wastewater treatment has a good processing effect and stable operation process.

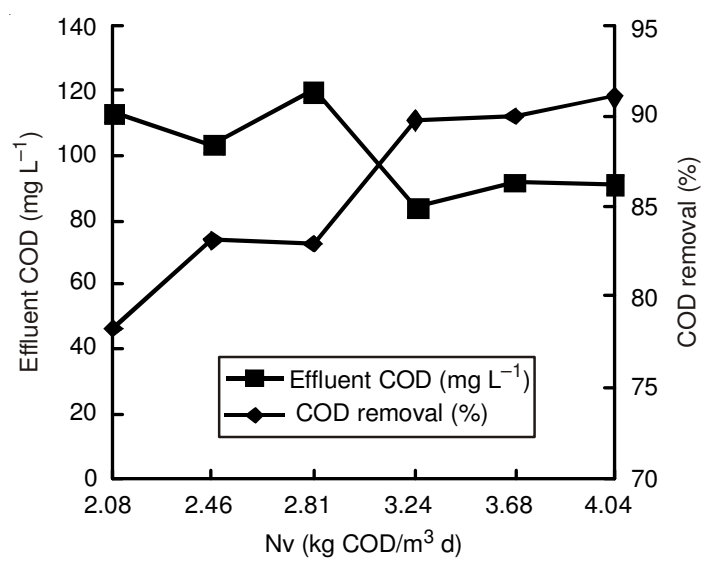

Fig. 4. Relations of organic load and elimination rate of COD

Fig. 5 shows the relation between $\mathrm{pH}$ and COD removal under the conditons of infullent $\mathrm{pH} 7.85$, infullent COD 300 $\mathrm{mg} / \mathrm{L}$, temperatrue $30{ }^{\circ} \mathrm{C}$ and hydraulic retention time $6 \mathrm{~h}$. From Fig. 5, the COD removal increases along with the $\mathrm{pH}$ value decreasing. The removal rate of COD of No. 1 chamber and No. 2 chamber are significantly faster than No. 3 chamber and No. 4 chamber and pH of No. 1 chamber and No. 2 aslo varies faster, which is associated large acidizing bacteria of the No. 1 chamber and No. 2 chamber that remove much COD. During operation, the removal rate of COD is more stable, basically above $80 \%$.

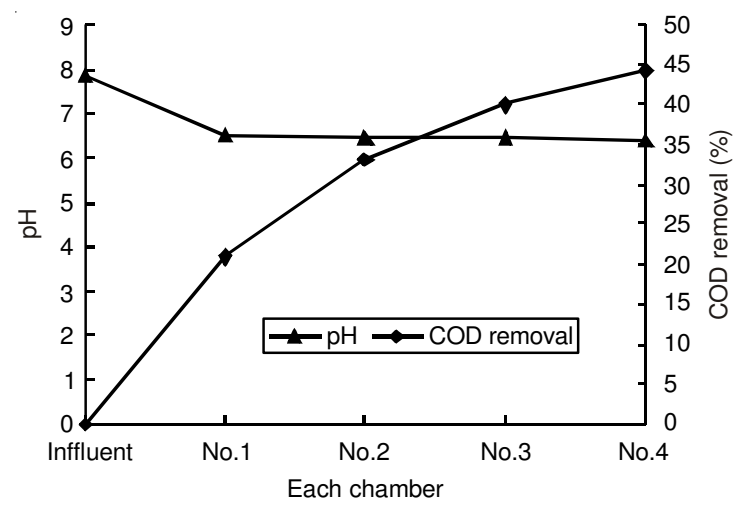

Fig. 5. Relation between $\mathrm{pH}$ and COD removal

Fig. 6 shows the relation between $\mathrm{pH}$ and volatile fatty acid under the conditons of infullent $\mathrm{pH} 7.23$, infullent COD $500 \mathrm{mg} / \mathrm{L}$, temperatrue $30^{\circ} \mathrm{C}$ and hydraulic retention time $6 \mathrm{~h}$. The volatile fatty acid of No. 1 chamber is higher than other chambers, which suggests that the acidification of No. 1 chamber is stronger than other chambers. In this role, the corresponding $\mathrm{pH}$ value of No. 1 chamber is declined. In contrast, the volatile fatty acid of the later three chamber are gradually declined and $\mathrm{pH}$ increasing because methanogenesis of the later three is stronger and the volatile fatty acid generated in No. 1 chamber is consumed.

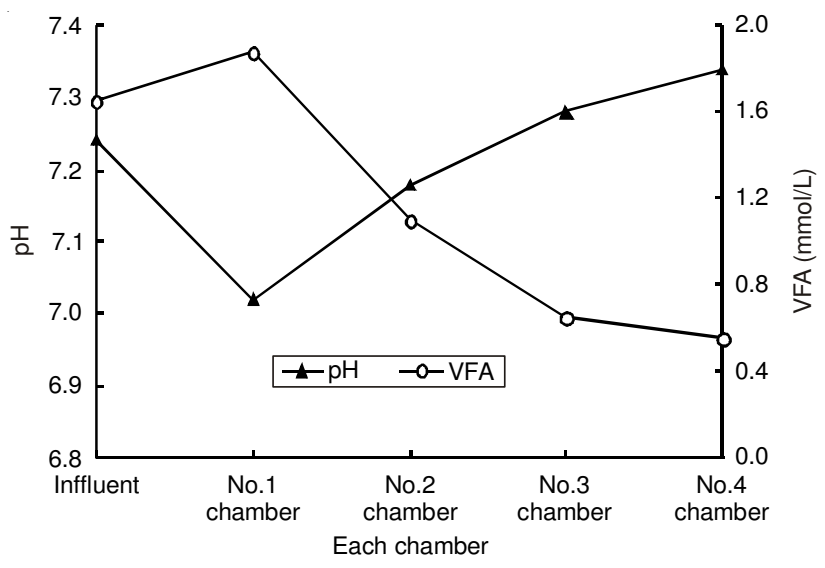

Fig. 6. Relation between $\mathrm{pH}$ and volatile fatty acid

Fig. 7 shows, when hydraulic retention time is $4-8 \mathrm{~h}$, the effulent alkalinity decreases gradually. But when hydraulic retention time increases from 8-10 h, the effulent alkalinity increases. Because the methanogens generation cycle is longer, when hydraulic retention time was short, the methanation rate of anaerobic reactor is low, organic acids can not be fully used. When hydraulic retention time reaches to $10 \mathrm{~h}$, methanation rate increases, so that effulent alkalinity increases.

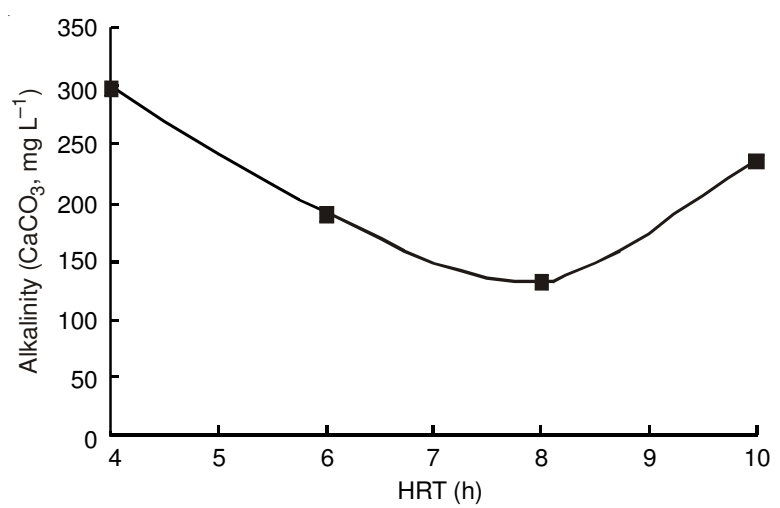

Fig. 7. Effluent alkalinity of different hydraulic retention time

\section{Conclusion}

The anaerobic baffled reactor designed with unequal length folded plate composite chambers and elastic stereo filler to treat domestic sewage get the good mass transfer efficiency and improved the biochemical reaction rate. Under the conditions of inffulent COD 500-1000 mg/L, temperatrue $(30 \pm 2)$ ${ }^{\circ} \mathrm{C}$, hydraulic retention time $6 \mathrm{~h}$, COD removing rate was more than $80 \%$. pH, volatile fatty acid were also important factors for treating efficiecncy and they affected the methanogenic activity.

\section{REFERENCES}

1. J. Akunna and M. Clark, Bioresour. Technol., 3, 73 (2000).

2. L. Angenent, G. Banik and S. Sung, Water Environ. Res., 5, 73 (2001).

3. G.V.T. Gopala Krishna, P. Kumar and P. Kumar, Bioresour. Technol., 17, 99 (2008).

4. S.W. Hu, F.L. Yang, S.T. Liu and L.Q. Yu, Water Res., 2, 43 (2009).

5. F. Nasr, H. Doma and H. Nassar, Environmentalist, 3, 29 (2008).

6. K.M. Foxon, S. Pillay, T. Lalbahadur, N. Rodda, F. Holder and C.A. Buckley, Water SA, 5, 30 (2004).

7. I. Manariotis and S. Grigoropoulus, Water Environ. Res., 2, 74 (2002). 